\title{
EXPERIENCE IN DEVELOPING THE EDUCATIONAL PROGRAM "ARCHAEOLOGICAL RESEARCH IN CONSTRUCTION"
}

\author{
Larisa Maslikhova ${ }^{1}$, Nadezhda Khakhulina ${ }^{2}$, Valery Barinov ${ }^{3}$, Olga Radugina ${ }^{4}$ \\ ${ }^{1}$ Candidate of Historical Sciences, Associate Professor, Voronezh State Technical University, \\ 20 years of October Street, 84, Voronezh, Russia, E-mail: maslikhova@vgasu.vrn.ru \\ ${ }^{2}$ Candidate of Technical Sciences, Associate Professor, Voronezh State Technical University, \\ 20 years of October Street, 84, Voronezh, Russia, E-mail: hahulina@mail.ru \\ ${ }^{3}$ Doctor of economics, Professor, Voronezh State Technical University, \\ 20 years of October Street, 84, Voronezh, Russia, E-mail: kafedravgasu@yandex.ru \\ ${ }^{4}$ Doctor of philosophy, Professor, Voronezh State Technical University, \\ 20 years of October Street, 84, Voronezh, Russia, E-mail: radugina@yandex.ru
}

\begin{abstract}
The design and subsequent construction of objects of any purpose requires engineering and archaeological research. The production of archaeological works is not complete without construction equipment, geodetic tools that allow you to solve a large number of tasks in the research process and also requires complex software that will allow you to perform the necessary calculations, simulate the area or object of research, etc. Therefore, the idea of combining historical science - archeology with technical science is innovative, meets the ideas of interdisciplinarity and integration of scientific knowledge.
\end{abstract}

Keywords: archaeology, geodesy, construction, research, master's program, competencies, interdisciplinarity

\section{INTRODUCTION}

Cultural heritage objects (historical and cultural monuments) of the peoples of the Russian Federation represent a unique value for the entire multi-ethnic people of the Russian Federation and are an integral part of the world cultural heritage.

State protection of cultural heritage objects (historical and cultural monuments) is one of the priority tasks of the state authorities of the Russian Federation, state authorities of the subjects of the Russian Federation and local self-government bodies.

The Russian Federation maintains a unified state register of cultural heritage objects (historical and cultural monuments) of the peoples of the Russian Federation (hereinafter referred to as the register), which contains information about cultural heritage objects.

The register is a state information system connected to the infrastructure that provides information and 
technological interaction of information systems used to provide state and municipal services in electronic form, and includes a data Bank, the unity and comparability of which is ensured by the General principles of forming the register, methods and forms of maintaining the register.

The information contained in the register is the main source of information about cultural heritage objects and their territories, as well as about zones of protection of cultural heritage objects, protection zones of cultural heritage objects in the formation and maintenance of state information systems for urban development, other information systems or data banks that use (take into account) this information.

To be included in the register, in addition to a set of descriptive data, information about the boundaries of the territory of the identified cultural heritage object is required, including a graphic description of the location of these borders, a list of coordinates of characteristic points of these borders in the coordinate system established for maintaining the Unified state register of real estate, etc.

Accordingly, all the necessary work requires specialists: historians, archaeologists, who, in addition to knowledge of historical facts, could fully own the tools, programs and technologies used in the field of construction and geodetic surveys.

In this regard, there is a need to train specialists who must have the competence to understand, perform and ensure the implementation of the entire range of works on the identification, study and preservation of cultural heritage objects.

\section{METHODOLOGY}

The methodological principles of the work are based on an interdisciplinary approach based on a set of General scientific methods of knowledge and special methods of information analysis. In particular, we used empirical methods-observation, survey, questionnaire, and expert evaluation. Theoretical methods were applied, including the study and analysis of domestic and foreign psychological and pedagogical literature; systematization of research materials; modeling; generalization.

\section{DISCUSSION}

Traditionally, "archaeology" is considered a humanitarian discipline and therefore in all existing educational programs refers to the historical Sciences. As a rule, a graduate of the master's program "Archeology" is prepared for such types of professional activities as teaching, research, cultural and educational, expertanalytical, organizational and managerial. Thus, the main types of professional activity of an archaeologist are associated with work as a teacher of higher education, a researcher specializing in archaeological research, an employee of archaeological departments of museums, an expert in conducting historical and cultural examinations, a state or municipal employee in the field of protection and use of historical and cultural heritage. The objects of professional activity are historical processes and phenomena in their sociocultural, political, economic dimensions and their reflection in historical and archaeological sources; archeologized remains of ancient cultures (archaeological monuments, archaeological objects, ancient artifacts.

Such educational programs are implemented in many leading universities of the Russian Federation (MSU, NSU, SPbSU, Southern Federal University, VSU, etc.). Voronezh state technical University has developed a master's program "Archaeological research in construction", which is of an interdisciplinary nature and is primarily practice-oriented.

\section{RESULTS}

For the implementation of this program, the basis was taken from the standard of FSES 3++ 08.04.01 "Construction". This standard defines universal (CC) and General professional competence (OPC). To acquire practical experience, skills and knowledge in solving professional tasks, professional competencies (PCs) are required, which are formulated based on professional standards. For this program, there is no professional standard( PS), so for the implementation of the program "Archaeological research in construction" were used PS code 10 "Architecture, design, geodesy, topography and design" and PS 40 "end-to-End professional activities in industry", in particular, from this standard is taken the code PS 40.011 "Specialist in research and development".

Among the possible types of professional tasks defined by the standard "Construction", the survey and research were chosen, which most accurately reflects the goals of the program "Archaeological research in construction". Research in the area of archaeology has several target areas. First of all, it is the identification of cultural heritage objects, determining their position in the spatial component of the environment and inhouse processing of the data obtained, followed by their mapping and documentation. Also, the purpose of 
archaeological research is to study the objects of cultural heritage on land plots allocated for economic development. This type of work is necessary to ensure that newly built or reconstructed buildings and structures do not cause the loss of valuable historical artifacts.

Based on the above-mentioned professional standards, the following professional competencies are defined to ensure the development of the program:

PC 1-ability to carry out work on processing and analysis of scientific and technical information and research results

PC 2-ability to use normative and technical documentation in the field of construction activities for planning and performing engineering and geodetic and archaeological surveys

PC 3-ability to apply modern methods, methods, techniques and technologies for preparing construction solutions

PC 4-the ability to perform urban planning, spatial, territorial, demographic, sociological, economic research, topographic and cartographic surveys, analysis, forecast, modeling, experiments necessary for the development of construction documentation.

According to the authors, successful development of these competencies will be provided by the following disciplines and practices of the curriculum in the part formed by the participants of the educational program

Academic disciplines:

Field research in archaeology.

Modern methodological concepts in archaeology and the history of archaeological science

Problems and methods of modern archaeological research

Geodesic support for archaeological research

Archaeological support of construction works

Organization and Economics of archaeological research during construction works

Protection of cultural heritage

Legal regulation in the field of preservation of objects of archaeological heritage

Legal regulation of construction works

Computer technologies in design and construction

BIM technologies at the stage of construction design and archaeological research

Cameral processing of archaeological finds: laboratory restoration and conservation of archaeological items

Dating methods in archaeology

Modern technologies in archaeological research: Russian and foreign practice

3-D modeling of archaeological heritage sites

Practices: Fact-finding practice. Design practice.

Electives: Interdisciplinary Studies in Archeology.

Museumification projects for archaeological heritage sites

In the modern world, specialists with a wide range of technical knowledge and skills are increasingly required, so the development of the presented competencies will allow graduates of the program to meet modern requirements. Each competence is mastered by a set of disciplines.

The competence of the PC-1 is provided by the following disciplines: modern methodological concepts in archaeology and the history of archaeological science; problems and methods of modern archaeological research; familiarization practice; project practice; interdisciplinary research in archaeology; projects of museification of objects of archaeological heritage.

To master this competence, the future specialist needs to know the basic principles of the system approach, as well as the principles of methodological approaches of various disciplines used in interdisciplinary archaeological research. Be able to work with the basic terminology for interdisciplinary research; analyze, correlate and highlight the most important information for the archaeologist as a result of applying the 
methods of related disciplines. Possess the skills of complex research; skills of using classical research methods in archaeology and creative scientific thinking, which allows to adapt the methods of related disciplines to archaeological research

PC-2 provides the following disciplines: geodesic support for archaeological research; regulatory and legal regulation in the field of preservation of archaeological heritage; regulatory and legal regulation of construction works; familiarization practice.

Knowledge and skill in using normative and technical documentation in the performance of construction works, engineering and geodesic and archaeological surveys will allow the specialist to effectively solve problems in the professional sphere. At the moment, the industry Fund of normative and technical documents (STD) regulating construction, geodesic and archaeological work includes such types of documents as: laws, regulations, state standards (GOST), building codes (Snips), codes of rules( SP), instructions, manuals and regulations, etc. Regulations for conducting archaeological surveys regulate the procedure and requirements for conducting field work and reporting. NTD in geodetic surveys determine the requirements for accuracy and composition of field and Desk work.

PC-3 provide the following disciplines: field research in archaeology; computer technologies in design and construction; BIM technologies at the stage of construction design and archaeological research; Desk processing of archaeological finds: laboratory restoration and conservation of archaeological objects; Dating methods in archaeology; modern technologies in archaeological research: Russian and foreign practice; 3-D modeling of archaeological heritage objects; technological practice.

Today, no industry is complete without computer technology. The need to implement modern technologies is explained by the requirements to reduce the time of design, field and Desk work, automation of processes, processing and analysis of information received. BIM technologies allow you to collect, process and systematize all the information in the process of archaeological research in a single information space and then use it to solve various tasks, such as evaluating economic, technological, design and planning characteristics, for three-dimensional visualization of objects, etc.

PC-4 provides the following disciplines: archaeological support of construction works; organization and Economics of archaeological research during construction works; protection of cultural heritage; technological practice; design practice.

Currently, specialists need to analyze large amounts of professional information in the course of research to develop urban planning solutions. As well as to carry out urban planning, spatial, territorial, demographic, sociological, economic research, topographic and geodesic, engineering and geological cartographic surveys necessary for the development of construction documentation. Process the received information, including using automated information systems, generalize and systematize information in various types and forms in the field of construction.

Thus, archaeological research in construction is a complex of works that consist of knowledge of different areas (disciplines), so it is obvious that an interdisciplinary approach should be used in the implementation of this master's program. Inter-disciplinarity is especially well implemented in the course of practical training, during which all the knowledge obtained in the course of classroom training is consolidated and assimilated.

\section{CONCLUSION}

The authors propose the structure of the implementation of the master's degree program in the direction of "Archaeological research in construction". Four professional competencies are proposed, the development of which will allow graduates of the program to master the necessary set of skills to perform archaeological surveys on land plots allocated for economic development.

\section{REFERENCE LIST}

Hahulina N.B., Maslikhova L.I., Akimova S.V. (2019) Modern technologies applied to archaeological research in Voronezh region // IOP Conference Series: Earth and Environmental Science C. 032037. (in English).

Khakhulina N.B., Trukhina N.I., Ivanov B. T. (2020). He role of competence approach in formation of functional literacy of learners. // 7th INTERNATIONAL CONFERENCE ON EDUCATION AND SOCIAL 
SCIENCES Abstracts \& Proceedings. Pp. 128-133. (in English).

Khakhulina N.B., Popov B.A., Netrebina Yu.S., Kharitonova T.B (2020). About design methods in education. // 7th INTERNATIONAL CONFERENCE ON EDUCATION AND SOCIAL SCIENCES Abstracts \& Proceedings.Pp. 102-107. (in English).

Maslikhova L. I., Petrenko V. R., Korshunova S. A. (2019) Achievements of technical education of the Voronezh region as a guarantee of successful development of the country and the region (rev. On the book: 110 years of technical education of the voronezh region: anniversary edition. Voronezh: VSTU publishing house, 2018. 240 p). Bulletin of the Voronezh state University. Series: Problems of higher education № 4. Pp. 114-117. (in Russian).

Maslikova L. I. (2015) Distance learning. Problems and prospects. Scientific Herald of the Voronezh state University of architecture and construction. Series: Social and humanitarian Sciences. № 3 (7). Pp. 94-99 (in Russian).

Maslikhova L. I., Khakhulina N. B., Akimova S. V. (2018). City, urban environment and features of conducting archaeological research. Problems of social and humanitarian Sciences. № 1 (14). Pp. 7 13. (in Russian).

Federal law "on objects of cultural heritage (historical and cultural monuments) of the peoples of the Russian Federation" of 25.06.2002 N 73-FZ (last edition). (in Russian).

The law of the Voronezh region of $05.05 .2015 \mathrm{~N} \mathrm{46-OZ} \mathrm{"about} \mathrm{features} \mathrm{of} \mathrm{legal} \mathrm{regulation} \mathrm{of} \mathrm{the} \mathrm{relations}$ connected with preservation, use, popularization and state protection of objects of cultural heritage in the territory of the Voronezh region" (ed. of 25.05.2018). (in Russian). 